Revista de
Economild
Contemporâned

\title{
"PROPERTY" RIGHTS AND THE WAYS OF PROTECTING ENTITLEMENTS - AN INTERDISCIPLINARY APPROACH
}

\author{
Maria Tereza Leopardi Mello ${ }^{a}$

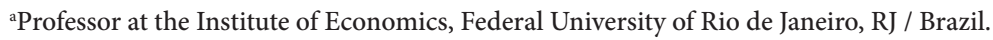

Manuscript received on 2015/10/23 and accepted for publication on 2016/11/21.

\begin{abstract}
This paper discusses the concept of "property" rights in an interdisciplinary perspective (Law and Economics) in order to compose an analytical conceptual framework to issues related to appropriability involved in public goods (PG) and common pool resources (CPR) analysis. Firstly, we discuss the differences between legal and economic concepts of property rights, trying to integrate economic and legal analytical elements: a right is an opportunity for current or future uses of an asset that is guaranteed by legal system (an enforceable power to maintain the control over economic opportunities). Although economists may not be concerned if some opportunity is guaranteed (or not) by law, nor whether its entitlement is made by means of property or by some other kind of right, these differences also matter for economic analysis. To deal with this question, we need to open the "black box" of the so called "property" rights: a) identifying and analyzing the different ways in which rights are entitled - from a legal perspective (Hohfeld) and in the footsteps of studies analyzing the economic relevance of the differences between property and possession, or property, liability and inalienability (Calabresi and Melamed); b) breaking down the concept of property rights in many faculties and analyzing them as a bundle of rights (Schlager and Ostrom). By way of conclusion, we discuss the possibilities of integrating these approaches and explore some of the implications of the study. From a public policies perspective, a more detailed understanding may assist in policy formulation (e.g., to break down and assign specific rights to different holders, etc.), and designing new forms of entitlements, or even the creation of new "assets" that could become the subject of rights.
\end{abstract}

KEYWORDS: property rights; entitlements; bundle of rights; law and economics.

JEL: K11.

Corresponding author: Maria Tereza C. Leopardi

Email address: leopardi@ie.ufrj.br 


\title{
PROPRIEDADE E OUTRAS FORMAS DE PROTEÇÃO DE DIREITOS - UMA ABORDAGEM INTERDISCIPLINAR
}

\begin{abstract}
RESUMO: Este trabalho discute o conceito de direitos de "propriedade" numa perspectiva interdisciplinar (direito e economia), de modo a compor um quadro conceitual para análise de questões relacionadas à apropriabilidade relacionadas a bens públicos e common pool resources. Primeiramente, discutem-se as diferenças entre os conceitos jurídico e econômico de propriedade, buscando-se integrar os elementos analíticos das duas disciplinas: um direito é uma oportunidade de uso - atual ou futuro - de um ativo garantida pelo sistema jurídico (uma forma de manter o controle sobre oportunidades econômicas). Embora os economistas não se preocupem em saber se uma oportunidade é ou não garantida pelo sistema jurídico, tampouco se a garantia se faz por meio de propriedade ou outros tipos de proteção legal, tais diferenças importam para a análise econômica. Para tratar dessa questão, é necessário abrir a "caixa preta" dos assim chamados direitos de "propriedade", (a) identificando as diferentes formas de atribuição de direitos; (b) destrinchando o conceito de direitos de propriedade em várias faculdades e analisando-as como feixe de direitos. A guisa de conclusão, discutem-se as possibilidades de integrar as diferentes abordagens apresentadas ao longo do trabalho, e se exploram algumas implicações para políticas públicas.
\end{abstract}

PALAVRAS CHAVE: direitos de propriedade; atribuição de direitos; feixe de direitos; direito e economia. 


\section{INTRODUCTION}

The aim of this paper is to discuss the concept of "property rights" in an interdisciplinary perspective (Law and Economics) focusing the issues of rights involved in public goods $(\mathrm{PG})$ and common pool resources $(\mathrm{CPR})^{1}$ analysis.

In most part of the economic literature, the idea of common pool resources and public goods almost always ends up referring to the famous tragedy of the commons (HARDIN, 1968), caused by the lack of appropriation. Despite the criticism to Hardin's work, there is some consensus that the unrestrained resource exploitation - in open access basis - leads to overexploitation and degradation; thus, some kind of appropriation system would be desirable for improving the ability to preserve the resources (COLE, 2000, p.280).

The problems are, then, approached in a property rights basis or through governmental regulation. In both cases, the solutions to the "tragedy" would be the enforcement of a property regime (substituting the open access regime) - whether private, common, or state (COLE, 2000).

Although many authors have pointed out the superiority of individual private property regime, the issue is controversial; numerous works - theoretical and empirical - not only challenge the effectiveness of private property system for preservation of natural resources, but also point to various forms of property and/or regulation ${ }^{2}$ which may be more or less suitable - and effective - to each circumstances and to different resources ${ }^{3}$.

Therefore, in order to discuss which would be the more suitable system in a certain context, one must surpass the (false) dilemma "individual private property" or "free access", as if they were the only two appropriation regimes.

In this article, we intend to analyze the property rights issue with the approach built by Schlager and Ostrom, whose work contributed decisively to understand the diversity - and complexity - of property systems, and seems well suited to the analysis of CPRs and PGs; but to this analytical framework, we add two more points: first, when it comes to assign rights for the use of resources, we must remember that the way in which rights are entitled matters, and there are different modes of entitlement, not restricted to "property" (CALABRESI and MELAMED, 1972).

1 Common-Pool Resources (CPRs) are resources with the attributes of non-excludability (an attribute typical from public goods) and some degree of rivalry (typical from private goods). Most research on CPRs have been related to natural resources - fisheries, grazing, water - but there is a growing interest in applying the concept to areas involving other non-natural types of shared resources (like knowledge, buildings, genetic data, etc.) (HESS, 2008). The concept will be analysed in section 3 .

2 Including the property rights based environmental regulation.

3 For a review of this debate, see Cole (2000). 
Secondly, there is an inextricable element of a legal nature in this discussion - one cannot deal with "rights" without referring to a legal system; this legal dimension cannot be ignored, including the use of concepts ${ }^{4}$.

Property rights issue is a typical interdisciplinary topic of debate, usually associated to the field of Institutional Economics and Law \& Economics; attention is focused on the economic effects of various forms of assignment of legal rights. But in the area of Law, there are few works dealing with property rights with the same concerns, and, even amidst interdisciplinary Law \& Economics literature, little attention is given to the fact that the meanings of the concepts used in this discussion are different in the two disciplines. Compared to the vast economic literature on property rights - from the years 50/60 - only recently economists have been interested in the legal issues ${ }^{5}$ like the differences between property and possession, property and liability, in rem and in personam rights and so on (HODGSON, 2015).

We will begin with the conceptual differences, in the first section (1), analyzing the legal and economic perspectives on property rights, and trying to formulate a concept that integrates elements of both approaches - an interdisciplinary concept - in order to relate the legal protection to economic performance. Section 2 presents the analytical framework from Calabresi and Melamed (1972), identifying the different ways of protecting entitlements. Thereafter, in Section 3 we turn to the conceptions of property as a bundle of rights (OSTROM, 1999; SCHLAGER and OSTROM, 1992). Section 4 will discuss the possibilities of integrating these approaches.

\section{RIGHTS AND "PROPERTY" RIGHTS: AN INTERDISCIPLINARY VIEWPOINT}

Despite the consecrated use by economists, the term "property rights" from the economic literature has little to do with the meaning ascribed to it in the legal realm. Here, a right is a legally recognized and protected interest; but not every interest is a right, nor every right is property (2.1).

4 In many circumstances, the term "property rights" is not always appropriate to describe and analyse the problem, as it will be analysed in section 1 .

5 With exceptions: for instance Kirat (1999) noting the inadequacy of naming "property" certain rights characterized as liability; Arruñada and Garoupa $(2003,2005)$ discussing the differences between rights in rem and in personam, and the distinct ways of transmission of rights; Heinsohn and Steiger (2002) stressing the difference between property and possession; De Soto (2000, apud HODGSON, 2015), about the role of formal property for collateralization; Calabresi and Melamed (1972), addressing the effects of the different legal ways of protecting entitlements. 
The economic literature has built an entirely own conceptual framework; but if we are worried about to integrate the legal and economic elements some "translations" are required. It is important to analyze the economic notion of property rights, understanding the possible matches with the legal concepts of rights (possession and property included) as well as the expressions of de jure and de facto rights (2.2) in order to explore the possibilities of an interdisciplinary concept with the necessary links between legal and economic elements (2.3).

\subsection{WHAT IS A PROPERTY RIGHT FROM A JURIDICAL POINT OF VIEW?}

Certainly, it depends on each national legal system, but we can consider some general features that are widespread in Civil Law countries.

According to Brazilian Law, property is a right in remand it consists in a direct and immediate power that an individual has towards a thing ${ }^{6}$ - material or immaterial, movable or immovable. In order to enjoy this power, the holder does not need any intervention or intermediation from third parties; the existence of the right places its object directly related to the holder of the right, regardless of any act or provision from a particular person (PEREIRA, 2011).

A property right may be seen as a bundle of basic rights, namely the rights of possession, use (usus), fruition (usus fructus) and alienation of the subject of the right. These rights, however, may or may not belong to the same holder. Property always requires a formal title and necessarily depends on the legal system. The full property includes the right to exercise possession.

Rights in rem are always previously defined by law, preventing individuals from creating or modify the content of such rights through private arrangements. In Brazil, they include not only the property, but also the possession, use, fruition, mortgage, pawn, among others ${ }^{7}$.

Unlike property, however, possession is a fact which occurs when someone actually exercise any of the faculties of ownership ${ }^{8}$ with animus domini. In Brazilian law system, possession may give rise to certain rights ${ }^{9}$ (even deserving a judicial protection).

\footnotetext{
6 More precisely, it is not a "relationship" between a person and a thing, but "relations between people respecting things" (COLE and GROSSMAN, 2002).

7 As defined by Civil Code (art. 1225).

8 According to Brazilian Civil Code, art. 1196, the faculties inherent to the property right are the use, enjoy and dispose of the thing.

9 The rights of receive the fruits, retention from improvements, transfer by inheritance or inter vivos, the acquisitive prescription, e.g.
} 
In principle, possession focuses on material goods, but one can also possess immaterial assets ${ }^{10}$ (trademarks and patents, e.g.). However, possession is always exerted on a thing - material or immaterial -; one cannot classify as possession the rights concerning obligations.

Also worth mentioning are the real guarantee rights (in rem rights over another's thing - mortgage e.g.), whose existence stems from the legal title which allows the separation of the various faculties on the same "thing" and their allocation to different holders. Thus, it allows the owner to continue using the thing, while it is encumbered and serves as collateral (HEINSOHN and STEIGER, 2002).

In contrast, the rights created by private relations (contracts, torts, unilateral actions) are submitted to different rules; such rights are seen to establish a relationship between two (or more) people by creating obligations. They are called rights in personam (or obligational rights).

Another perspective of viewing such differences is to consider the correlative duties to each right: for rights in personam, the enforceable duty is an obligation of one or more specific people to do something, or to give something, or to not do something. In the case of rights in rem, the corresponding duty is an obligation of all people (indistinctly) not to disturb the holder - all people have the corresponding duty not to interfere with the holder's possession and use (COLE and GROSSMAN, 2002).

In both cases, the condition of having a right supposes a jural relation: the conception of "rights" must be understood within a jural relation between two parties (one holding a faculty of doing/deciding something; the other being required to fulfill an obligation - correlative to that faculty).

However, although it is often said that "a legally enforceable right presumes a legally enforceable duty", jural relations do not always fall under the strict definition of rights and correlative duties (COLE and GROSSMAN, 2002, p.317). Besides in rem and in personam rights, there are other kinds of legally recognized interests, whose ways of protection differ - sometimes significantly - from each other.

The legal literature distinguishes what we can name as rights (stricto sensu) from other kinds of legally protected interests, according to Hohfeld's analytical system (HOHFELD, 1913); the jural relations include:

- rights and correlative duties;

- privilege (liberty) and the correlative no-claim (or no-right);

- power and the correlative liability;

- immunity and the correlative disability. ${ }^{10}$ In some circumstances, it is also admissible the possession of rights to which it is possible to exert
dominion power (possession of a telephone line, e.g.). 
The privilege/liberty in the decision-making process is the faculty to do or not to do something in a free choice basis. This comes from a general principle in legal systems: no one is obliged to do something unless expressly commanded by law; therefore, in the absence of a specific law commanding behaviour, individuals are free to decide whether or not to do something ${ }^{11}$. In this case, there is no correlative duty, but only the fact that no one else has the 'right' to prevent someone from doing something ${ }^{12}$ (COLE and GROSSMAN, 2002). Thus, the correlative of liberty is no-right (or no-claim).

From a legal point of view, liberty simply means the absence of duty - that's why, in Hohfeldian framework, duty is a term considered the opposite ${ }^{13}$ to liberty (or privilege). However, in an economic perspective, liberty means choice of opportunities, and its correlative (no-claim) can also be understood as exposure (COMMONS, 1959). For instance in competition process, the competition strategy picked out by an agent (within the limits allowed by the antitrust laws) can even cause damage to competitors, without this damage should be avoided or compensated by legal means. This situation is referred to as damnum absque injuria (the possible damage without legal wrong, remedy or protection). So, the term exposure "....includes all of the possibilities of damage to which one is exposed without remedy through the operations of free competition in buying and selling" (COMMONS, 1959, p.98).

Rights and liberties presuppose relationships created by "rules of conduct" (behavior rules) - establishing coordination relationships (FERRAZ Jr., 1988, p.158); on the other hand, subjection (subordination) relationships are created by "competence rules"- giving rise to powers and immunities.

Such rules create power and subjection: the power of one party and the correlative liability of the other ${ }^{14}$; or, when establishing restrictions to power, immunity and the disability (no power) (FERRAZ Jr., 1988). In this context, power means the ability to "effect the particular change of legal relations that is involved..." (HOHFELD, 1913, p.44), and it is to be noted that these class of relationships refers also to that from the public sphere, which require the exercise of sovereign power.

\footnotetext{
${ }^{11}$ Some authors use to distinguish between this kind of liberty (as lack of prohibition) and the faculties supposing an explicitly provided permission to do or not to do something (which should be classified as rights), according to Ferraz Jr. (1988).

${ }_{12}$ To claim "a right to do something" is different from claiming that "no one else has the right to prevent you from doing it" (a freedom).

${ }^{13}$ Commons (1959) prefer to designate these relationships as "mutually defined limits" instead as "opposites". According to him, right and no-right (or no-claim) are notions delimiting each other: one goes until where the other begins. So it would be mutually delimited the concepts of liberty-duty, powerdisability, immunity-liability.

${ }^{14}$ The creation of an agency relation, for example, involves "the grant of legal powers to the so-called agent, and the creation of correlative liabilities in the principal" (HOHFELD, 1913, p.46).
} 
In short, one can summarize the different class of jural relations:

A right is one's affirmative claim against another, and a privilege is one's freedom from the right or claim of another. Similarly, a power is one's affirmative 'control' over a given legal relation as against another; whereas an immunity is one's freedom from the legal power or 'control' of another as regards some legal relation (HOHFELD, 1913, p.55).

It is not our intention to go deeper into this subject, but only to draw the attention to the following: (i) "right" is a broad term which presupposes a legal relationship with three elements - two parties ${ }^{15}$ and an object ${ }^{16}$ (LOPES, 1994, p.115); (ii) to have a right means to have an interest that is recognized and protect by the legal system; (iii) there are different ways of protecting these interests; (iv) the classification of the jural relations - as rights (in rem or in personam), liberty, power or immunity - describes different objects of a relationship and different relations between parties; in doing so, it determines the legal regime establishing the faculties attached to these legal interests, the actions for defense, etc. ${ }^{17}$ So, the classification implies different degrees of protection and guarantee of those rights ${ }^{18}$.

Obviously, these differences matter for the enforcement of the Law; and, to some extent, they matter also to economic analysis.

\subsection{AND WHAT ARE PROPERTY RIGHTS FOR ECONOMISTS?}

Economic analysis does not distinguish among those different classes of legally protected interests, all of them being usually designated - regardless their legal status - as property rights.

The economic literature presents some conceptual differences in property rights definition ${ }^{19}$ but for the purpose of this paper, we can look at some paradigmatic definitions of New Institutional Economics:

\footnotetext{
${ }^{15}$ A party can be an individual or a group of individuals, a firm, etc. One is the holder of a faculty and another having a correlative obligation or subjection.

16 To give, to do, not doing, omitting, etc.

${ }_{17}$ See Cole and Grossman (2002) for examples of American jurisprudence based on the differences of Hohfeldian jural relations.

${ }^{18}$ For convenience, we will continue to use the term "rights" to designate not only rights stricto sensu (and its correlative duty), but also the other kinds of legally protected interests, with the broader meaning that encompasses liberty, power and immunity.

${ }^{19}$ For a review of property rights concepts in the economic literature, see Cole and Grossman (2002).
} 
Property rights are an instrument of society and derive their significance from the fact that they help a man form those expectations which he can reasonably hold in his dealing with others (DEMSETZ, 1967, p.347).

I define the economic property rights an individual has over a commodity (or an asset) to the individual's ability, in expected terms to consume the good (or the services of an asset) directly or to consume it indirectly through exchange (BARZEL, 1997, p.03).

(...) property rights involve the assignment of exclusive decision making over valuable resources (...). (LIBECAP, 1993, p.05)

[Ownership rights are] expectations a person has that his decision about the use of certain resources will be effective. (ALCHIAN and ALLEN, 1969, apud UMBECK, 1997, p.51)

Three points are noteworthy in these settings: first, both conceptions of "property rights" are much broader then the legal one: they include not only the other kinds of legal rights not classified as property ${ }^{20}$, but even some attributes of an asset not protected by any right (in the legal sense).

Second, these "rights" are seen as a set of faculties (powers) of the holder, who can act or decide to do or not to do something, or how to employ his/her assets.

Third, and more importantly, the emphasis is placed on expectational element, which relates to the use of future possibilities of an asset ${ }^{21}$; such expectations/ possibilities are crucial for defining the system of incentives, but economists are not concerned about whether they are guaranteed by a legal system or not.

We are not saying that the economic definition is "wrong", although it does not match the legal one ${ }^{22}$, but only pointing out the differences in approaching the issue, arising from the fact that the concerns of the economic analysis are distinct: within the economic analysis what matters is not so much what the agents can legally do, but what they believe they can do or control, as signalized by Monteiro and Zylberstajn (2011, p.100) in their analysis of Barzel's concept of economic property rights ${ }^{23}$. These

${ }^{20}$ Including all the rights over "things" (in rem) - possession, usus fructus, pawn, mortgages, etc. -, and also personal rights, liberties, power and immunities.

${ }^{21}$ And not the fact that someone is legally considered the owner of a set of assets acquired in the past. From the economic perspective, it does not matter if someone is entitled to accumulated goods, but if one can profitably use these assets in the future.

22 Nevertheless the use of the same terms to designate different contents could be a source of misunderstandings, in both areas, as discussed in Cole and Grossman (2002).

${ }^{23}$ Barzel distinguishes between legal and economic property rights: "The term 'property rights' carries two distinct meanings in the economic literature. One,..., is essentially the ability to enjoy a piece of property. The other (...) is essentially what the state assigns to a person. I designate the first 'economic (property) rights' 
economic rights set the incentives for the agents; that is why the legal rights are neither a necessary nor a sufficient condition for the existence of economic rights.

In this analytical framework, economic and legal property rights are independent from each other and non excludent: an economic right could be also a legal one - or not - and vice versa. Combining economic $\left(\mathrm{PR}_{\mathrm{ec}}\right)$ and legal property rights $\left(\mathrm{PR}_{\text {law }}\right)$, we can have three hypotheses:

i. $\mathrm{PR}_{\mathrm{ec}}\left(\right.$ no- $\left.\mathrm{PR}_{\mathrm{law}}\right)$ : an economic right means the agent believes he can do something, but there is no legal guarantee;

ii. $\quad \mathrm{PR}_{\text {law }}\left(\right.$ no- $\left.\mathrm{PR}_{\mathrm{ec}}\right)$ : the juridical system protects some interest, but in an ineffective degree, so the agent cannot count with the legal protection and does not have any expectation about it;

iii. $\mathrm{PR}_{\mathrm{ec}}+\mathrm{PR}_{\mathrm{law}}$ : expectation of using an asset is reinforced by the legal protection.

A feature of this approach is pointing out the multiple dimensions of the assets: there may be many uses associated with a good/service; economists tend to individualize each dimension of them and call each of them as if it were a right.

From this perspective, the legal protection matters to the extent it provides a greater possibility of third-party exclusion, strengthening the holder's ability to consume the services of an asset (MONTEIRO and ZYLBERSTAJN, 2011, p.100). But the lack of legal protection doesn't prevent the economists from calling the mere use of some opportunity as a "right" (or even a property right - what in the legal world is a treatment of one kind of rights in rem, as seen above in 2.1).

In the legal realm, however, one could only speak about rights if a certain dimension of an asset could be detached from the main asset and protected as such by the legal system $^{24}$. Actually, juridical concerns are of two levels: (i) whether an interest is legally protected or not; (ii) the way it is protected.

In general the judiciary adjudicates rights considering such differences, as analyzed in Cole and Grossman (2002) $)^{25}$; they also examine the concepts of "property rights" of

and the second 'legal (property) rights. Economic rights are the end ..., whereas legal rights are the means to achieve the end" (BARZEL, 1997, p.03). While acknowledging the usefulness of the author's statement, it sounds very strange - from a legal point of view - to claim that there may be a "right" that is not legal.

${ }^{24}$ For instance, the location of a house - suppose with a beautiful view, beachfront, - it is an important dimension that even turns it more expensive; but is not detachable attribute. The value of this dimension is not in itself guaranteed as a right. If the attribute of the location changes - the view is lost by the construction of a taller building in front, for example - the owner who paid for it will suffer a loss not compensable in principle (unless this has explicitly been set as a right). From the economic point of view, the location could be taken as an "economic right", although not a legal one.

${ }^{25}$ The authors give several examples of American jurisprudence based on the Hohfeldian class of jural relations. 
economic literature, showing the inconsistency of these concepts with legal ones, as well the inadequacy of the term "rights" to describe the mere exercise of certain actions, confusing "the doing of something - mere use - with the right to do it", or conflating "right" with "ability" or interest (COLE and GROSSMAN, 2002, p.10). It is true that some uses and customs can rely on social approval and be allowed (sometimes even against the law), but that does not automatically transform them into rights.

A good example given by Cole and Grossman is about illegal pollution: the fact that a polluter has generated pollution for a long period of time without opposition could create the expectation of continuing to pollute. This may even present economic value, since the agent has the perspective of not internalizing the pollution costs; but does not ensure a right to pollute, as well as their neighbors do not have a corresponding obligation to suffer pollution without compensation. One does not become a right holder from the mere fact of earning profits from the opportunity to pollute. As analyzed by Cole and Grossman (2002), the U.S. courts do not recognize as a right the mere use without opposition or penalty.

Thus, while pollution may be, say, a reality resulting from a weak and inefficient legal system, it is likely that such behavior does not count on the approval of the affected social group (in the sense that no one admits the power to pollute). Nevertheless, it is a usage that an economist would call economic property right.

This brings to controversial issue: is the role of legal guarantee essential to the conformation of rights? The legal guarantee (meaning the possibility of the right to be enforceable by the state) is an intrinsic attribute to the idea of law, which directly affects the expectations of being able to rely on the use of an asset. Nevertheless, this safeguard does not rely only on the State's coercion: social approval - meaning that a group of people agree to assign and maintain certain assets under the control of certain individuals or groups - can also operate as or more effective than the legal guarantee. We can say, therefore, that the guarantee can be derived from a legal or from a conventional order with some empirical validity ${ }^{26}$.

The existence of the legal (or conventional) guarantee as well the way it is enforced affect the shaping of expectations and transaction costs. In the absence of such

\footnotetext{
${ }^{26}$ An order consists in a set of conventional or legal rules. In the former, the obedience is guaranteed by general sanction diffusely applied by the group. In a legal order the guarantee is due to a formalized and institutionalized action of a group of individuals whose mission is to enforce the rules and punish deviation (WEBER, 1978, p.34). Economic social action is oriented by an order when its rules are seen as mandatory or as model to be followed; which raises the probability of the action actually being in accordance to the rules of a valid order - whether legal or conventional. In a similar meaning, Hodgson's analysis points the role of the legal system in the individual motivation (HODGSON, 2015).
} 
guarantee, transactions involving economic rights would have to be self-enforced; transaction costs tends to be higher, the expectations weaker ${ }^{27}$. In this sense, the guarantee increases the safety required by economic agents to maintain their present or future power of disposition on assets (WEBER, 1964), which is crucial to the allocation of rights.

Even the economic concept of rights - as expectation of controlling an asset - it seems to need for a minimum of social recognition to ensure the appropriability ${ }^{28}$. In fact, part of the economic literature on property rights indicates the formal protection (the legal system) and/or social recognition on the allocation of certain privileges/ faculties to individuals or groups as necessary elements for the definition of property rights $^{29}$. But in the Barzel's conception of economic property rights social approval is not required (although it is sometimes implied in some examples given by the author). In this case, economic rights include also usages and customs ${ }^{30}$ not sanctioned by any order.

The issue of guarantee - its existence and its form - is also involved when comparing the concept of property rights of economic literature with the legal concepts of property and possession ${ }^{31}$, and with de facto and de jure rights.

${ }^{27}$ Without of institutionalized guarantee from the State, the existence of repeated, systematic and impersonal transactions in a world of uncertainty and incomplete contracts would be put at risk - in other words, the transaction costs would be prohibitive. As noted by North, It would be difficult to sustain a complex system of exchange out of an enforcement system carried out by a third party, which could use the force if necessary (NORTH, 1993).

${ }^{28}$ If any actual action - without any safeguard - is designated as a "right", this term will no longer be use full (since it does not assign any kind of especial situation).

${ }^{29}$ As in Libecap: “... property rights must be clearly specified and enforced to be effective, and the degree of specificity depends upon the value of the asset covered. For relatively low value assets and/or in cases where the number of parties is small and where there is a history of interaction, informal norms and local customs are sufficient for defining and enforcing property rights. For high-valued assets where the number of competitors is large and where new entry is common (so the parties are heterogeneous and have little or no history of interaction), more formal governance structures, such as legally-defined private property rights, become necessary. In this latter case, the power of the state is usually necessary to suplement informal constraints on access and use" (LIBECAP, 1999, p.05). For Umbeck, property rights exists to the same extent that people agree to respect them, or when the owner can exclude those who do not respect; but cease to exist if others take them, or if somehow the exclusivity is lost or ceases to be respected (UMBECK, 1997, p.39).

${ }^{30}$ We employ the terms in the Weberian meaning: usages are "empirical uniformities" actually observed, whose "probability of its existence within a group is based on nothing but actual practice. ... A usage will be called a 'custom' ... if the practice is based upon long standing." Usage and custom "...may be said to be 'determined by self-interest' if and insofar as the actors' conduct is instrumentally ... oriented toward identical expectations" (WEBER, 1978, p.29). In the example discussed by Cole and Grossman (2002) cited above, it is characterized a usage - the polluter acts based on self interest as long as possible, which does not transform the actual usage in a right.

${ }^{31}$ Check the debate between Hodgson (2015), Cole (2015), Barzel (2015), and Allen (2015). 
At first, the notions of de facto and de jure rights match Barzel's concepts of economic and legal rights respectively, as the author himself admits ${ }^{32}$. In both conceptual pairs - de facto/de jure rights and economic/legal rights - the terms are not mutually exclusive $^{33}$ (not dichotomous, as explained above). Legal/de jure rights are provided by a legal order; de facto/economic rights may refer either to faculties (appropriation) socially accepted (conventionally protected) as to effective usages and customs.

These conceptual pairs, however, have no direct correspondence to the legal concepts of possession and property ${ }^{34}$, which relate to in rem rights. Differently, de facto/de jure rights and economic/legal rights cover also many other personal relations. That is, de jure/legal rights are not necessarily property rights in the legal sense, in that they can be constituted by others kinds of legal entitlement (right sin personam, liberties, etc.); in the same way, de facto/economic rights are not necessarily possession.

But it may be some intersections between these categories ${ }^{35}$. First of all, in legal sense property corresponds to de jure/legal rights, because it presupposes - always - a formal title guaranteed by the state; even though not all de jure/legal rights are property.

Possession, in turn, is a matter of fact - occurs when someone has the physical power over something and uses it with animus domini; it can be exercised (i) by the owner; (ii) by a non-owner who has the rights of usus fructus, for instance; (iii) by a non-owner without any legal basis. In the latter case, even without having been originated from a legal title, ownership can generate some rights (as seen above). Furthermore, even in the lack of legal basis, ownership can be socially recognized by a group of people who respect the possession of certain individuals or groups.

So, possession could be partially identified to de facto/economic rights, when these ones have a thing as its object. On the other hand, even if de facto/economic rights are related to things, they cannot be confused with possession (since that there may be other ways of economically exploring an asset - thing - independent from possession).

In short, de facto/economic rights and de jure/legal rights are broader conceptions; when these "rights" have a thing as its object, they can match the notions of possession and property, respectively. Economic/de facto rights can be connected either with usages and customs, as with conventions (when there is social approval, assuming a

\footnotetext{
32 "As I use the concept, property rights consist of legal rights (de jure) and economic rights (de facto)" (BARZEL, 2015, p.719).

${ }^{33}$ It should be taken as ideal types.

34 The following analysis on the differences between possession and property refers to the Brazilian legal system - although some of its features are common to some Roman Law tradition countries.

${ }^{35}$ It is difficult to establish a clear relationship between these concepts because each pair belongs to a distinct "conceptual family", with their specific fields of references and with different concerns.
} 
conventional order); while legal/de jure rights are related to $\operatorname{law}^{36}$, remembering that all these concepts must be seen as types, and not as excludent classifications.

But anyway, could those differences - between economic and legal approaches be considered just as a mere nominalistic issue, like Allen (2015) proposes ${ }^{37}$ ? It is true that the differences can lead to some confusion, but would it not be enough to identify what each discipline defines as the meaning of the same word?

I would say no: if economic analysis itself concerns with the effects of the allocation of "rights" on the behaviour of agents and with the economic outcomes, then it is important to take into account if these very rights are guaranteed or not, and by what means. When calling "rights" the mere usage, economists ignore the whole debate in the legal area and fail to incorporate legal elements of analysis that could be useful to address the issue.

\subsection{AN INTERDISCIPLINARY CONCEPT}

As we have seen, the economic notion of property rights presents some intersections with the legal concept, but is not limited to it. The economic view includes not only the distinct types of rights (lato sensu), but sometimes also includes interests not protected by law; likewise, there may be rights by the law not effectively protected, to which an economist would not designate as economic property rights.

In order to clarify this difference and to integrate economic and legal analytical elements, we will use two concepts from Weber (as discussed in MELLO and ESTEVES, 2010). i) First, there is the concept of economic good or service (an asset) as a set of opportunities for current or future uses ${ }^{38}$. This set of opportunities can be used jointly or separately, by one or more individuals, at different times. For economic concerns, what matters is to keep the power to control such opportunities. A crucial aspect of the economic property rights conception is expectations - concerned not with accumulated wealth, but with assets whose present value depends on the opportunities of their employment in the future. Therefore, the economic conception is close to the Weberian notion of "control over opportunities", which also contains a dimension related to

\footnotetext{
${ }^{36}$ For definitions of usages, customs, conventions and law, see footnotes 26 and 30 above.

${ }^{37}$ In his response to Hodgson's criticism (HODGSON, 2015).

38 Economic action is guided by these opportunities. One can buy an asset expecting that it will be useful - it will generate profits or satisfy needs -, but what he acquires, in fact, is an opportunity to use it in different ways (SWEDBERG, 2005).
} 
expectations - of maintaining that power of disposal and control ${ }^{39}$. And ii) second, there is the concept of "right", for which the external guarantee and institutionalized sanction are crucial elements. To have a right means to have a legally recognized interest and to be able to use the coercive apparatus of the State (the Judiciary) to ensure this interest.

Accordingly, in a set of opportunities, some are handled by the legal system - these can be regarded as rights. The legal system may provide greater or lesser possibilities to detach these opportunities and transfer them separately from each other (which has economic implications - collateralization is only one example). Hence the importance of the concepts of bundle of rights (as discussed below) and different ways of entitlements, described above.

The figure below provides the economic and legal concepts, relating one to each other and highlighting their differences.

Figurei 1 - Economic and legal perspectives about property rights: distinctions and correspondences

\begin{tabular}{|l|l|l|l|}
\hline \multirow{2}{*}{ Economic concerns } & \multicolumn{2}{|c|}{ Juridical concerns } \\
\hline \multirow{2}{*}{$\begin{array}{l}\text { Power to profit from economic opportunities } \\
\text { (of using an asset), by maintaining the } \\
\text { control over such opportunities. }\end{array}$} & $\begin{array}{l}\text { Opportunities } \\
\text { guaranteed by } \\
\text { the legal system } \\
\text { legally recognized } \\
\text { interests + right } \\
\text { of action }\end{array}$ & Rights & Liberty \\
\cline { 2 - 4 } \cline { 3 - 4 } & in personam \\
\cline { 2 - 3 } & Power \\
\cline { 2 - 4 } & $\begin{array}{l}\text { Opportunities (uses and interests) not } \\
\text { guaranteed by the legal system }\end{array}$ \\
\hline
\end{tabular}

Source: Author's elaboration, adapted from Mello and Esteves (2010).

On the left side, the economic concerns relate to the expectation of using an asset and the control of opportunities. Some of these opportunities could be controlled by means of juridical protection: they constitute rights in a legal perspective, represented on the right side of the figure. Among them, we can to distinguish the many ways of entitlements (the many ways of protecting interests). In the side of the juridical concerns, the distinction between the existence or not of the legal protection is relevant, in that only the interests protected by law could be called "rights".

\footnotetext{
${ }^{39}$ Weber uses this concept to discuss the relationship between law and economics: the law affects the interests of the individual because it originates probable opportunities of keeping control over economic assets, or to acquire the power over them in the future by certain preconditions (WEBER, 1964).
} 
It should be noted that our approach to rights follows the school of the legal realism - i.e., if we say that the legal protection matters (for the economic analysis as well), we are not only referring to the normative statement, but to the effective working of the legal system when it adjudicates rights in specific cases ${ }^{40}$. In this sense, "to have a right" is always to have an expectation of being able to use the right of action; in Weberian terms, it is equivalent to having a legally protected interest in favor of which one can ask for help from state coercive mechanism ${ }^{41}$.

That is why the right of action is part of the concept of rights: it is through it that the state machine is moved, giving "substance" to the normative provision. As Commons (1959) puts it, the procedural remedy cannot be considered "merely" formal; in fact, the legal realism view reverses the substantial/formal notions:

It's the "form" that now is reality, for it is none other than the actual behavior of officials which is the only legal reality that we really know. And that which was 'the substance' is now only the ethical and legal ideal, the wish, the hope of something that ought to exist but may or may not exist. (COMMONS, 1959, p.112)

Summing up, although economists may not be concerned with whether a given opportunity is guaranteed by law or not, nor its entitlement is made by means of property or by some other kind of right, it should be emphasized that these juridical differences also matter for economic analysis, since:

i) The protection of an interest by law affects the degree of security one can count on to keep control on opportunities. Different legal regimes affect the way a right can be created, maintained, modified and transferred. To that extent, the legal regime affects the degree of safety with which one can rely on the maintenance of the power to use an asset, affecting expectations therefore.

ii) The existence of well-defined and guaranteed rights to an asset affects its transferability, to the extent that it reduces transaction costs.

iii) In some circumstances, legal protection is a crucial means of appropriability regarding immaterial goods ${ }^{42}$ or intangible assets ${ }^{43}$ (since "physical" appropriation is impossible).

\footnotetext{
${ }^{40}$ The law must be considered not only as an abstract rule, but as all its operating process. (MELLO, 2014)

${ }^{41}$ Commons' analysis is very close to the Weberian one: "Legal rights and duties are none other than the probability that officials will act in a certain way respecting the claims that citizens make against each other" (COMMONS, 1959, p.125).

${ }^{42}$ E.g., patents, trademarks, etc.

${ }^{43}$ E.g., the goodwill.
} 
iv) In many cases, legal title increases the potential profitable employment of $\operatorname{goods}^{44}$.

To the extent that these features are relevant for economic analysis, legal institutions defining - and protecting - rights may affect economic agents' decisions as well as their results.

Rights are relevant because they are able to create - and strengthen by the legal guarantee - the expectations for the future use of an asset.

In the next sections we intend to deepen the discussion about the need to (i) distinguish between different forms of entitlements (CALABRESI and MELAMED, 1972), as well as (ii) disentangle the various "powers" involved in property rights (SCHLAGER and OSTROM, 1992; OSTROM, 2000), always trying to integrate the economic and the legal views.

\section{THE LEGAL MEANS OF PROTECTING ENTITLEMENTS}

In the previous section we stressed not only the importance of the existence of legal protection but also the different ways in which this protection is enforced by the legal system. Such differences are relevant: i) because they affect the degree and the actual results of protection; ii) because they influence relevant economic variables (such as allocation and distribution of resources).

This latter issue is addressed by Calabresi and Melamed's article. They drew attention to the importance of the legal form of protection when distinguishing entitled rights according to whether they are protected by property, liability or inalienability rules. The distinction is viewed from the perspective ${ }^{45}$ of the faculties granted to the right holder, in particular, those related to the exclusion and to alienation (and the role of the state in this process).

Property exists when the right is transferrable only through a voluntary transaction in which the owner agrees with the purchaser about the price and other conditions.

In contrast, the right will be protected by the liability rule when the owner can be deprived of his right by means of damages payment, irrespective of his will.

\footnotetext{
${ }^{44}$ For instance: legal property (which means not only the legal protection but, in particular, the way of protection, assuring the many faculties of ownership and allowing its allocation to different holders) is fundamental to the establishment of collaterals, allowing the object continues to be used by the owner at the same time it is encumbered with the mortgage/pawn (HEISOHN, STEIGER and DE SOTO, 2000).

45 Which the authors emphasize as only one from many other possible viewpoints - "one view of the cathedral".
} 
Other rights are protected by a rule which excludes them - total or partially - from the possibility of being exchanged, i.e., by inalienability - a way of entitlement which involves a greater degree of societal intervention: "the law not only decides who is to own something and what price is to be paid if it is taken or destroyed, but also regulates its sale - by, for example, prescribing preconditions for a valid sale or forbidding a sale altogether"(CALABRESI and MELAMED, 1972, p.1111).

On the other hand, the three entitlement forms represent increasing degrees of state intervention. Under the property rule, "once the original entitlement is decided upon, the state does not try to decide its value", provided it is voluntarily agreed by the parties. Under the rule of responsibility, the indemnification value will be ultimately decided by an organ of the State. In the case of inalienability, the degree of intervention is greater, since there must be a law forbidding - total or partially - the sale of some goods (CALABRESI and MELAMED, 1972, p.1092).

The authors go on to discuss the reasons by which the entitlements are defined and, more important for our point, they stress the crucial role of the law enforcement process, analyzing how differences in the way of protecting entitlements matter for economic analysis, to the extent that they affect the economic results of such entitlements.

A liability rule can be justified: i) on grounds of economic efficiency - when transaction costs are high (due to information asymmetry or in a circumstance where bargain is impossible) liability rules are a more efficient way to protect entitlements; ii) for distributional reasons (CALABRESI and MELAMED, 1972, p.1108-10).

Inalienability rules can also be better, under certain circumstances, for efficiency reasons: when the transaction could create externalities; when external costs are not measurable (moralism); self-paternalism; true paternalism (supposing that someone is not in position to choose best for himself when he made the choice). Finally, inalienability may be motivated by distributional concerns, since: "whether an entitlement may be sold or not often affects directly who is richer and who is poorer" (CALABRESI; MELAMED, 1972, p.1113).

An illustrative example can be seen in the recent judgment by the Brazilian Supreme Court (Supremo Tribunal Federal) in an action of unconstitutionality (ADIN 4815), discussing the conflict between two constitutional rights: the right to privacy/intimacy on the one hand, and the right to free expression and information, on the other; the question was referring particularly to unauthorized biographies, whose publication would violate the biographee's right to privacy. Until then, the prevailing judicial interpretation favored the biographee ("B"), which could prevent the author ("A")from publishing his work, if privacy/intimacy was to be threatened. This implied: 
"B" have a right and imposes to "A" a duty not to do something (in this case, not be published).

"B" had the decision power; the biography would only be published if he had consented (or if "A" had been able to buy the consent, paying the price " $\mathrm{B}$ " had stipulated).

The judgment of the Supreme Court, however, has changed this interpretation, understanding that the author ("A") can publish his work regardless of the biographee's authorization; if the biographee feels harmed in his or her image or privacy, he or she can seek damages. Even though both rights remain valid, judicial decision affected the weighting between them. This implies that: $A$ has a power to cause harm to $B$ 's interest; and $B$ has his interest protected by the liability rule, and may seek damages (whose value shall be ultimately defined by the judiciary).

As can be seen, the change in judicial interpretation has affected the distribution of resources (understood here in the broad sense - any kind of "wealth", as rights in this case): according to the first interpretation, $B$ was better off than in the second, and his or her interest prevailed in relation to $A$ 's. The price of the right was defined by $B$. According to the second interpretation, $B$ is poorer than in the previous one, and his or her interest is in a balance in relation to $A$ 's. The price of the right is defined by the state.

The example also serves to emphasize the importance of law enforcement in the effective setting of rights. In this case, the constitutional rules remain exactly the same, but a new interpretation altered the distribution of "resources" (affecting the distribution of rights and the allocation of duties).

A last remark: although property rights (in the juridical sense, as a right in rem) have, in general, the characteristic of being transferable only by the owner's will ${ }^{46}$, the concept as used by Calabresi and Melamed has a broader scope, in that it can encompass rights not related to a "thing". From another standpoint, liability rules may apply to some situations that would be considered legally as property rights in the sense of rights in rem. For example, if one considers a patent as an intellectual property right, a hypothesis of compulsory license would involve a feature of liability rule (in Calabresi and Melamed's term), for the third party's access to the protected invention would be possible even against the will of its holder ${ }^{47}$.

\footnotetext{
${ }^{46}$ Some striking features of real rights have this function, e.g.: the right of pursuit, the type of procedure in which they prefer to always return the thing to the holder, only solving in damages if one cannot restore it, etc.

${ }^{47}$ A similar situation can be seen in cases of using the protected technology for research, or exemption for farmer's own use in the case of UPOV protection.
} 
These considerations are important to highlight that the categories defined by the authors should be understood as "types" rather than as a classification system. As a matter of fact, most entitlements - actually existing - are mixed (CALABRESI and MELAMED, 1972, p.1093).

\section{PROPERTY AS A BUNDLE OF RIGHTS}

The contributions of Ostrom for understanding the problems involved in public goods and common pool resources (CPRs)will be approached here from 3 standpoints (useful for our discussion):first, the clarifying use of the concepts; secondly, the overcoming of the dilemma "private property" vs. "tragedy of commons", and finally, the understanding of property as a bundle of rights.

Ostrom adopts the property rights concept from Commons, defining it as "(...) an enforceable authority to undertake particular actions in a specific domain" (apud OSTROM, 1999), and adds: "[p]roperty rights define actions that individuals can take in relation to other individuals regarding some 'thing"'48 (OSTROM, 1999, p.339).

The concept of "rights" focuses on the effective power to use its object, whatever the "source" of this power. If the source is the state legal system, Schlager and Ostrom say there is de jure rights - enforced by a government, with lawful recognition by legal system. If the rights are defined and enforced by the resource users themselves ${ }^{49}$, they are designed as de facto rights.

De jure and de facto rights are not mutually exclusive; both can co-exist, conflict or be mixed in real world. When de facto rights are uncontested, they affect the action as much as de jure rights. However, the differences become clear when the rights are challenged. In short, the legal guarantee makes difference, since de facto rights are less secure than de jure rights: "[R]ights-holders who have de jure rights can presume that if their rights were challenged in an administrative or judicial setting, their rights would most likely be sustained" (SCHLAGER and OSTROM, 1992, p.254).

\footnotetext{
${ }^{48}$ Ostrom's empirical analysis are related to things - natural resources, usually -, which denotes something close to the ideia of rights in rem. Butshe uses the term "property rights" in a broader sense, not strictly corresponding to the idea of in rem rights.

${ }^{49}$ In this case, the definition of de facto rights seems to assume the existence of a conventional order in Weberian sense, insofar as it relates to power exercised by individuals with the approval of the group they belong to.
} 
As we can see, the notion of de facto rights is an economic concept not much different from Barzel's economic rights ${ }^{50}$; it is equivalent to the effective actions denoting the power of control over the use of economic opportunities, but it does not fall into the class of legally protected interests (it is not a right, from a legal point of view). Schlager and Ostrom also understand de jure rights as an element that strengthens the guarantee/security one can put on the maintenance of the power of controlling opportunities ${ }^{51}$.

Another important distinction made by Ostrom is between the concepts related to the nature of goods and those related to the property regimes. The former have to do with some attributes of the goods themselves, the latter issue concerns the rules governing their appropriability.

Regarding the nature of goods, according to economic literature, they can be public or private, or characterized as Common Pool Resources (CPR). As Ostrom defined:

a broad class of phenomena called 'common pool resources' is a natural or man made facility that produces a flow of use units per units of time..., where exclusion from the resource is difficult or costly to achieve and the resource can potentially be utilized by more than one individual or agent simultaneously or sequentially (apud CORIAT, 2013, p.12).

Differently from private (appropriable) goods, public goods are non-excludable and non-rival ${ }^{52}$. Common Pool Resources share with public goods the attribute of non-excludability (in that it could be difficult/costly to exclude beneficiaries, whether by physical or by institutional means); on the other hand, like private goods, CPRs present the attribute of rivalry, since benefits consumed by someone subtract from the benefits available to others (OSTROM, 1999).

CPRs are composed of resource system (which generates a flow of benefits over time) and a flow of resource units or benefits from these systems ${ }^{53}$, and they may be

\footnotetext{
${ }^{50}$ The concepts are similar, with one difference: in the sense used by Schlager and Ostrom, de facto rights presuppose the existence of social approval, which is not a requirement in Barzel's "economic rights".

${ }^{51}$ As discussed earlier, de jure rights are not necessarily property rights in the legal sense, in that they can be constituted as another kind of entitlement (personal rights, liberties, etc.).

${ }^{52}$ This is an economic classification. In the legal literature the definition of public goods concerns the holder: cf. Brazilian Civil Code, art. 98, public goods are those belonging to public legal entities (i.e., Federal Government, State Government and municipalities and their agencies).

${ }^{53}$ Lakes, rivers, fishery stocks are examples of common pool resource systems, while water, and fish are resource units from a CPR.
} 
subject of different kinds of property regimes - i.e., they may be owned by governments, by communal groups, by private individuals or firms, or used by all without restrictions. As analyzed by Coriat (2013), the CPRs have attributes concerned to both stock and flux: a CPR consists of a core resource that can be considered as stock, but it can be withdrawn in a simultaneous or sequential way by individuals or groups, which gives rise to a flux (CORIAT, 2013, p.12).

$\mathrm{CPR}$, than, should not be confounded with common property nor open access, which are only possible alternative regimes for governing resource appropriability (or their units' appropriability).

In analyzing property regimes, Ostrom surpassed the dichotomy between "individual private property" and "open access system" as being the only two possible alternatives for appropriation of the fruits of an asset, emphasizing the need to distinguish between common property and open access system.

Common property is not opposed to private property, since it is characterized by excluding non holders - the property right can be held by one or more individuals. In the latter case, it is said that there is a common property. In a common property, the members of a clearly demarked group have the legal right to exclude nonmembers, from using a resource.

In an open access system, no one has the legal right to exclude anyone from using a resource, and if a resource generates highly value products, "then one can expect that the lack of rules regarding authorized use will lead to misuse and overconsumption" (OSTROM, 1999, p.336).

According to the author, there are three types of open access: i) res nullius - by lack of rules about the use or the ownership of a resource ${ }^{54}$; ii) jus publicum - as a result of an express decision of public policy to ensure access of all citizens (e.g. beaches, squares, etc); iii) ineffective exclusion - where there is an entity to whom the rights are formally assigned, but it cannot effectively exclude others ${ }^{55}$.

Property regime is a general concept, each regime supporting several possible combinations of rights (multiple powers to take actions regarding a particular thing). Thus, a property regime and the many faculties provided by its rules must be analyzed

\footnotetext{
"Terras Devolutas" (unoccupied lands) in Brazilian legislation would be an example.

${ }^{55}$ Ostrom gives an example: during the 1960's, many developing countries nationalized natural resources (land and water) that was not recorded as private property: "The institutional arrangements that locar users had devised to limit entry and use lost their legal standing, but the national government laked monetary resources and personnel to monitor the use of these resources effectively. Thus, resources that had been under a 'de facto' common property regime enforced by local users were converted to a 'de jure' government-property regime, but reverted to a 'de facto' open access regime' (OSTROM, 2000, p.337).
} 
jointly. In order to deal with it, it is useful to break down the concept of property rights in many faculties, analyzing them as a bundle of rights, as do Schlager and Ostrom (1992).

Distinguishing the rights of access, withdrawal, management, exclusion and alienation is another way to focus the entitlement issue, from the perspective of the faculties conferred to the holder of each right. A synthesis can be seen in the table below:

Figure 2 - Bundles of rights associated with positions

\begin{tabular}{|c|c|c|c|c|c|c|}
\hline \multicolumn{2}{|c|}{ Powers/faculties associated with the right } & \multirow{2}{*}{$\begin{array}{c}\text { Owner } \\
x\end{array}$} & \multirow{2}{*}{$\begin{array}{c}\text { Proprietor } \\
\mathrm{X}\end{array}$} & \multirow{2}{*}{$\begin{array}{c}\text { Claimant } \\
\mathrm{X}\end{array}$} & \multirow{2}{*}{$\begin{array}{l}\text { User } \\
\mathrm{X}\end{array}$} & \multirow{2}{*}{$\begin{array}{l}\text { Entrant } \\
\mathrm{x}\end{array}$} \\
\hline Access & $\begin{array}{l}\text { To enter a physical area } \\
\text { and enjoy nonsubtractive } \\
\text { benefits }\end{array}$ & & & & & \\
\hline Withdrawal & $\begin{array}{l}\text { To obtain resource units } \\
\text { or products of a resource } \\
\text { system }\end{array}$ & $x$ & $x$ & $x$ & $\mathrm{x}$ & \\
\hline Management* & $\begin{array}{l}\text { To regulate the use } \\
\text { patterns and transform } \\
\text { the resource by making } \\
\text { improvements }\end{array}$ & $x$ & $\mathrm{x}$ & $x$ & & \\
\hline Exclusion* & $\begin{array}{l}\text { To determine who will } \\
\text { have access and } \\
\text { withdrawal rights, and } \\
\text { how they can be } \\
\text { transferred }\end{array}$ & $\mathrm{x}$ & $\mathrm{x}$ & & & \\
\hline Alienation & $\begin{array}{l}\text { To sell or lease } \\
\text { management and } \\
\text { exclusion rights }\end{array}$ & $\mathrm{x}$ & & & & \\
\hline
\end{tabular}

Note: ${ }^{*}$ ) Collective choice rights

Source: Schlager and Ostrom (1992).

The rights of access and withdrawal are rights to access a particular good and to get fruits from it (they are equivalent to the legal concept of usufruct). Management and exclusion rights relate to the power to lay down rules on how to use a resource and who can use them, respectively. Alienation is the right to sell or in any way to transfer the rights of management and exclusion.

Each one of these rights may be held by the same or by different individuals or collectivities. Different species of right holders are classified according to the powers/ faculties attached to each right.

When the authors disentangle the many faculties (use, withdrawal, etc.) involved in the employment of an asset (or of a CPR units), they opened the "black box" of socalled "property rights", understanding them not as a monolithic block but as a bundle of rights, and identifying elements which are meaningful within both legal and economic spheres. 


\section{A SYNTHESIS OF THE DIFFERENT CONTRIBUTIONS}

We understand the approaches presented here as complementary, despite their different origins and affiliations. The first one builds a bridge between the law issue and the economic ones. The interdisciplinary concept of rights - as an enforceable power to maintain the control over opportunities - maybe compatible with Ostrom's property rights attributes and Calabresi's entitlements, and it allows us to deal with the links between legal protection and economic results.

These approaches can be useful for both descriptive and normative purposes. A large field for empirical research can be perceived, which involves comparative studies of local regulations to understand (i) what are the systems of rights and (ii) how they work in practice.

Regarding the legal aspects, we must know not only what the rules are, but mainly how they are actually enforced.

To the extent that they go deeper into the real diversity, they provide a conceptual and analytical framework for better describing - and better understanding - the relevant questions embedded in the CPRs exploitation.

More specifically, we believe that the following elements should be identified in an empirical analysis:

1) When analyzing the use one actually does - or can do - of an asset (of a good / a resource), one must distinguish between what is right and what is not guaranteed by state law (which can be an usual repeated action, with which one can count but has no legal warranty). Even if one is only concerned with the effective power over the use of the asset, the legal warranty matters.

2) The property regimes are not limited to full private or open access; there are several intermediate alternatives of assigning exclusive rights to more or less delimited groups of people. Even a public property (an area belonging to the state) or an open access system (related to public goods) can admit different regulatory regimes that grant some rights to individuals (e.g. property-rights based regulation, etc). On the other hand, even a totally private property system may be limited by others' rights, or by state regulation.

The rules of a property regime must be understood in their diversity - and from both legal and economic standpoints (de jure rights and de facto "rights"), noting that there may be an intersection between them.

3) The rights over a resource (or an asset) should not be considered as something monolithic, but as a bundle of more or less broad powers or faculties. Hence the importance of identifying: each single right over the resource; the individuals or groups that hold those rights (and the exercise of fact); the decision-making processes on the use of the resource. 
4) Different classes of rights have different degrees of protection, different ways in which they can be created, and these differences may affect economic results. Thus, the ways of entitlement matter not only for the legal analysis (Hohfeld), but also for their potential economic effects as well (CALABRESI and MELAMED, 1972). Following the path of Calabresi and Melamed, there is a broad space for empirical research in order to relate the forms of assigning rights (rights, liberties, etc.) to their functions and economic results.

5) The relevant legal analysis for the economic perspective of property rights is not restricted to the formalism of the normative world, but involves the effective result of the whole enforcement of the legal system. Thus, the enforcement process needs to be investigated because this is what defines the reality of law.

Apart from acknowledging that the very idea of a "right" is always a legal concept and as such it requires a legal or conventional order, we intend to emphasize that the economic analysis cannot be detached from the legal one, because: (i) whether economic interest is legally protected or not it affects the economic outcomes of the "right"; (ii) how one's interests (the rights, liberties, etc.) are protected can affect the degree of protection with significant distributional implications (affecting the incentive systems, too). In short, the Law's role is fundamentally related to the legal guarantee and its forms. The legal guarantee does not ensure, by itself, that the right will be effective, even less the ability of the holder to profit from his assets (it is not a sufficient or necessary condition for it).

The legal guarantee itself does not ensure that the right will be effective, even less the holder's ability to get profits from his/her assets (it is not a sufficient or necessary condition for it). These are questions to be detected in empirical research. At the micro level, the expectations of maintaining the power of control over an asset tend to be more assured when legal guarantee is present. Hence, this guarantee is one of the elements defining incentives, and then, a constituent element of economic concerns.

To discuss if rights are well defined and guaranteed in some specific situation, we need to know what actions might be taken in order to defend these rights (if lawsuits are possible, if there is a broad social recognition of the right, if there are alternative channels for solving conflicts, what are the dominant interpretations of the law, if the decisions are easily executable, etc.).

Finally, we can also explore some of the normative implications, discussing what legal forms of protection are more fitted to different social purposes. From public policies perspective, a more detailed understanding may assist in policy formulation (e.g., to break down and assign specific rights to different holders, etc.), and designing new forms of entitlements, or even the creation of new "assets" that could become the subject of rights. One can face many alternative ways of assign different powers for different holders. 


\section{REFERENCES}

ALCHIAN, A. A.; ALLEN, W. R. Exchange and production: theory in use. 2. ed. Belmont: Wadsworth Publishing Company, 1969.

ALLEN, D. W. On Hodgson on property rights. Journal of Institutional Economics, v. 11, n. 4, p. 711-717, 2015.

ARRUÑADA, B.; GAROUPA, N. The choice of titling system in Land. Journal of Law and Economics, v. 48, n. 2, p. 709-727, 2005.

ARRUÑADA, B.; GAROUPA, N. Property enforcement as organized consent. Journal of Law, Economics and Organization, v. 19, n. 2, p. 401-444, 2003.

BARZEL, Y. Economic analysis of property rights. Cambridge: Cambridge University Press, 1997.

BARZEL, Y. What are "property rights" and why do they matter? A comment on Hodgson's article. Journal of Institutional Economics, v. 11, n. 4, p. 719-723, 2015.

BROMLEY, D. W. Property rule, liability rule and environmental. Journal of Economic Issues, v. 12, n. 1, p. 4 3-60, 1978.

CALABRESI, G.; MELAMED, A. D. Property rules, liability rules, and inalienability: one view of the cathedral. Harvard Law Review, v. 85, p. 1089-1128, 1972.

COLE, D. H. "New forms of private property: property rights in environmental goods". In: BOUCKAERT, B.; DE GEEST, G. (Eds.). Encyclopedia of Law and Economics. Vol. II - Civil Law and Economics. Cheltenham: Edward Elgar, 2000. Available at: <http://reference. findlaw.com/lawandeconomics/1910-new-forms-of-private-property-property-rights-inenviornmental-goods.pdf>. Accessed Jan. 18, 2017.

COLE, D. H. Economic property rights' as "nonsense upon stilts": a comment on Hodgson. Journal of Institutional Economics, v. 11, n. 4, p. 725-730, 2015.

COLE, D. H.; GROSSMAN, P. Z. The meaning of property "rights": law versus economics? Land Economics, v. 78, n. 3, p. 317-330, 2002.

COLE, D. H.; GROSSMAN, P. Z. EPSTEIN, G.; MCGINNIS, M. D. Digging deeper into Hardin's pasture: the complex institutional structure of "the tragedy of the commons". Journal of Institutional Economics, v. 10, n. 3, p. 353-369, 2014. Available at: <http://journals.cambridge. org/JOI>. Accessed Dec. 23, 2016.

COMMONS, J. Legal Foundations of Capitalism. Madison: The University of Wisconsin Press, 1959.

CORIAT, B. From natural-resource commons to knowledge commons: common traits and differences. LEM Working Paper Series, n. 2011/16, 2011. Available at: <http://www.lem. sssup. it>. Accessed Nov. 22, 2015.

CORIAT, B. Le retour des communs: sources et origines d'un programme de recherche. Revue de la Régulation, n. 14, Autumn 2013. Available at: <http://regulation.revues.org/10463>. Accessed Sept. 08, 2014.

DEMSETZ, H. Toward a theory of property rights. American Economic Review, v. 57, n. 2, p. 347-359, may 1967. Available at: <http://jstor.org/stable/1821637>. Accessed Apr. 07, 2011. 
DE SOTO, H. The Mystery of Capital: why capitalism triumphs in the west and fails everywhere else, New York: Basic Books, 2000.

FERRAZ JUNIOR, T. S. Introdução ao Estudo do Direito: técnica, decisão, dominação. São Paulo: Atlas, 1988. Available at: <https://vademecumdireito.files.wordpress.com/2013/03/ introduo-ao-estudo-do-direito-tercio-sampaio-ferraz-junior.pdf >. Accessed Dec. 23, 2016.

HARDIN, G. The tragedy of commons. Science, v. 162, p. 1243-1248, 1968.

HEINSOHN, G.; STEIGER, O. “The property theory of interest and money”. In: SMITHIN, J. (Ed.). What is Money.Abingdon, UK: Taylor \& Francis E-library, 2002, p. 67-100.

HESS, C. Mapping the new commons. In: BIENNALCONFERENCEOFTHE INTERNATIONAL ASSOCIATION FOR THE STUDY OF THE COMMONS, 20, 2008. Available at: <http:// surface.syr.edu/sul>. Accessed Aug. 11, 2015.

HODGSON, G. M. Much of the "economics of property rights devalues property and legal rights. Journal of Institutional Economics, v. 11, n. 4, p. 683-709, 2015.

HOHFELD, W. N. Some Fundamental Legal Conceptions as Applied en Judicial Reasoning. The Yale Law Journal, v. 23, n. 1, p. 16-59, 2013. Available at: <http://www.jstor.org/ stable/785533>. Accessed Jun. 23, 2015.

LIBECAP, G. D. Contracting for property rights. New York: Cambridge University Press, 1993.

LOPES, J. R. Lima. “Direitos subjetivos e direitos sociais: no Estado Social de Direito". In: FARIA, L. E. (Org.). Direitos humanos, direitos sociais e justiça. São Paulo: Malheiros, 1994, p. 113143.

MELLO, M. T. L. Direito e economia em Weber. Revista Direito GV, v. 2, n. 2, p. 45-65, 2006.

MELLO, M. T. L. “O direito, a pesquisa empírica e a economia”. In: PORTO, A. M.; SAMPAIO, P. (Orgs.). Direito e economia em dois mundos: doutrina jurídica e pesquisa empírica. Rio de Janeiro: FGV Editora, 2014, p. 145-156.

MELLO, M. T. L.; ESTEVES, H. L. B. Property rights: building an interdisciplinary approach. In: COLLOQUE CHARLES GIDE, Paris, 2010.

MELLO, M. T. L.; ESTEVES, H. L. B. "O jurídico e o econômico na noção de direitos de propriedade intelectual”. In: HERSCOVICI, A. (Org.). Direitos de Propriedade Intelectual e Inovação: uma análise econômica além das evidências. Vitória: EDUFES, 2015, p. 51-83.

MONTEIRO, G. F. A.; ZYLBERZSTAJN, D. Direitos de propriedade, custos de transação e concorrência: o modelo de Barzel. Economic Analysis of Law Review, v. 2, n. 1, p. 95-114, 2011.

OSTROM, E. "Private and common property rights". In: BOUCKAERT, B.; DE GEEST, G. (Eds.). Encyclopedia of Law and Economics. Vol. II - Civil Law and Economics. Cheltenham: Edward Elgar, 2000. Available at: <http://reference.findlaw.com/lawandeconomics/2000private-and-common-property-rights.pdf >. Accessed Jan. 18, 2017.

PEREIRA, C. M. da SILVA. Instituições de Direito Civil. Vol. IV - Direitos Reais. 24. ed. Rio de Janeiro: Forense, 2011.

SCHLAGER, E.; OSTROM, E. Property-rights regimes and natural resources: a conceptual analysis. Land Economics, v. 68, n. 3, p. 249-262, 1992. 
UMBECK, J. "Might makes rights: a theory of the formation and initial distribution of property rights". In: PEJOVICH, S. (Ed.). The Economic Foundations of Property Rights: selected readings. London: Edward Elgar, 1997.

WEBER, M. Economía y sociedad. 2. ed. México DF: Fondo de Cultura Económica, 1964.

WEBER, M. Economics and society. Berkeley, CA: University Of California Press, 1978. 